\title{
CHARACTERIZATION OF FUNGAL INOCULUM USED IN SOIL BIOREMEDIATION
}

\author{
Nara Ballaminut ${ }^{1 *}$; Dácio R. Matheus ${ }^{1}$ \\ ${ }^{1}$ Seção de Micologia e Liquenologia, Instituto de Botânica, Secretaria do Meio Ambiente do Estado de São Paulo, São Paulo, \\ SP, Brasil
}

Submitted: September 12, 2006; Returned to authors for corrections: October 19, 2006 Approved: February 12, 2007.

\begin{abstract}
Studies have indicated the capacity of basidiomycetes to degrade recalcitrant organopollutants. However, the age of the fungal inoculum to obtain a more effective degradation has not been defined. The criterion used is total colonization of the substrate. Psilocybe castanella CCB444 and Lentinus crinitus CCB274 have been evaluated in soils containing hexachlorobenzene. In the present study, the physiological conditions of the fungal inocula were characterized on solid substrate (sugarcane bagasse, starch and soy flour). Colonization of the substrate, loss of organic matter, $\mathrm{pH}$ variation, organic carbon, total nitrogen, fungal biomass and enzymatic activity were evaluated over 30 days of incubation. Colonization of the substrate was almost complete after 20 days for both species, with about $90 \%$ of organic matter remaining on the substrates. The $\mathrm{pH}$ continued to be acid during incubation. The highest enzymatic production was observed at 10 days for $L$. crinitus and at 5 days for $P$. castanella. The fungi presented growth up to 30 days. The $\mathrm{C} / \mathrm{N}$ ratio of the inocula showed little variation. The use among 10 and 15-day-old inoculum is adequate since sufficient nutrients are left to guarantee survival of the fungus, vigorous colonization of the substrate, a growing biomass and an active enzymatic system, thus permitting fungal growth in soil.
\end{abstract}

Key words: ligninolytic enzymes, basidiomycetes, fungal inoculum, ergosterol

\section{INTRODUCTION}

The large-scale use of pesticides and recalcitrant detergents since the 1950s has resulted in the problem of accumulation of toxic compounds in the environment. Among the treatment alternatives, the possibility of soil bioremediation with ligninolytic basidiomycete fungi is being evaluated $(4,12,16,23,26)$.

Basidiomycete fungi possess the ability to degrade lignin as well as xenobiotic compounds. This correlation has been based on the observation of the ability of Phanerochaete chrysosporium to degrade numerous organic pollutants, with significant mineralization rates in some cases. Today it is known that this capacity is due to the presence of a nonspecific oxidative and extracellular multi-enzyme system $(2,7,9,18,21)$.

Culture and maintenance of basidiomycetes for application to these processes and the choice of appropriate substrates for inoculum production are of fundamental importance for a good performance of these fungi. However, despite the large number of studies on bioremediation using basidiomycetes, the exact time when the fungal inoculum has reached the conditions favoring degradation of the pollutant is still unknown. Usually, the inoculum is considered to be ready for use when the substrate is visually colonized with fungal mycelium, $(10,13,15,16,18)$. Soil bioremediation using basidiomycetes has been extensively studied but no parameter indicating the quality of the fungal inoculum for application to this process has been defined (10). The objective of the present study was to evaluate parameters indicating the quality of the inoculum for use in soil bioremediation.

\section{MATERIALAND METHODS}

\section{Fungi}

Lentinus crinitus CCB 274 and Psilocybe cf. castanella Peck. CCB444, deposited at the Basidiomycete Culture Collection

*Corresponding Author. Mailing address: Instituto de Botânica, Av. Miguel Estéfano, 3687, São Paulo, CEP: 04301-012, Brazil. Tel.: (11) 5073-6300 r.311. E-mail: narablg@uol.com.br 
(CCB) of the Botanic Institute, Departament of the Environment, São Paulo, Brazil.

\section{Fungal inoculum}

The inoculum was prepared using sugarcane bagasse enriched with soy flour and soluble starch, at predetermined C/ $\mathrm{N}$ ratios, according to Matheus and Bononi (15). The $\mathrm{C} / \mathrm{N}$ ratio was 90 for $P$. castanella (962 g sugarcane bagasse, $38 \mathrm{~g}$ soy flour (dry base) and $70 \%$ water) and 180 for L. crinitus $(825.33 \mathrm{~g}$ sugarcane bagasse, $3 \mathrm{~g}$ soy flour, $171.67 \mathrm{~g}$ soluble starch (dry base) and $70 \%$ water). The substrates were sterilized at $121^{\circ} \mathrm{C}$ and $1.2 \mathrm{~atm}$ for $90 \mathrm{~min}$. Thirty mycelial disks ( $5 \mathrm{~mm}$ in diameter) of fungi grown in $2 \%$ malt extract agar were inoculated into 1000 $\mathrm{g}$ of substrate and incubated at $28 \pm 2^{\circ} \mathrm{C}$. Aliquots of the colonized inocula were removed after $0,5,10,15,20,25$ and 30 days of incubation for the analyses described below.

\section{Dry weight of the fungal inoculum}

The dry weight was determined in triplicate by gravimetry in $10 \mathrm{~g}$ aliquots of the wet sample after drying for $12 \mathrm{~h}$ at $105^{\circ} \mathrm{C}$. Twenty-five milliliters of deionized distilled water was added to $10 \mathrm{~g}$ aliquots of each sample and the samples were shaken at $120 \mathrm{rpm}$ for $15 \mathrm{~min}$. The samples were left to rest for $1 \mathrm{~h}$, and the $\mathrm{pH}$ was then determined with a tec-2 pH-meter (Tecnal - São Paulo, Brazil).

\section{Estimation of fungal biomass by ergosterol quantification}

Aliquots of lyophilized inoculum ( $5 \mathrm{~g}$ ) were added to $26 \mathrm{~mL}$ saponification solution ( $20 \mathrm{~mL}$ methyl alcohol, $5 \mathrm{~mL}$ ethyl alcohol and $2 \mathrm{~g}$ potassium hydroxide), shaken at $250 \mathrm{rpm}$ for $20 \mathrm{~min}$, and heated to $70^{\circ} \mathrm{C}$ for $40 \mathrm{~min}$. After cooling, $5 \mathrm{~mL}$ sterile distilled water was added to the samples at room temperature, and the samples were centrifuged for $10 \mathrm{~min}$ at 10,000 rpm (Eppendorf, model F 40-6-38). A known volume of the supernatant was transferred to a separation funnel with an equal volume of P.A. $\mathrm{n}$-hexane and stirred manually for $2 \mathrm{~min}$. After resting for $10 \mathrm{~min}$, the $n$-hexane phase was recovered and the volume was recorded. The samples were evaporated in a rotary evaporator at $40^{\circ} \mathrm{C}$ under pressure and resuspended in HPLC methanol. Aliquots of the extract $(20 \mu \mathrm{L})$ were injected manually into the HPLC system (Varian, Pro Star Model 230). Ergosterol was separated on a C18 reverse-phase column (Varian 1215-9012) using methanol for isocratic HPLC as eluent at a flow rate of 2 $\mathrm{mL} \min ^{-1}$. The retention time of ergosterol ranged from 3.4 to 3.5 min. The quantity of ergosterol in the extracts was determined based on a standard curve constructed with known concentrations of ergosterol (Sigma, 90\% purity). Dry biomass was estimated according to Silva (24).

\section{Visual analysis of substrate colonization}

The percentage of colonization of the samples was analyzed visually after $0,5,10,15,20,25$ and 30 days of incubation. An arbitrary percentage of colonization was attributed by three independent observers in triplicate.

\section{Determination of the $\mathrm{C} / \mathrm{N}$ ratio in the inoculated substrate}

Organic carbon was determined as described by Kiehl (8) by digesting $0.2 \mathrm{~g}$ of dry sample with a sulfochrome solution in an exothermic reaction of potassium dichromate and sulfuric acid. Excess oxidizing agent resulting from the reaction was determined by titration with ferrous sulfate. Total nitrogen was determined by the Kjeldahl method, with modifications introduced at the Laboratory of Ecology, Botanic Institute. An aliquot of the dry sample $(0.27 \mathrm{~g})$ was weighed into $100 \mathrm{~mL}$ glass tubes and $8 \mathrm{~mL}$ of the cold digestion mixture was added (8). The tubes were slowly heated to $350^{\circ} \mathrm{C}$ in a digestion block where they were kept for $30 \mathrm{~min}$ after the second clarification of the sample. After cooling to room temperature, the tube was filled with distilled water until completing $100 \mathrm{~mL}$. The samples were distilled and collected into flasks containing boric acid and an indicator mix (bromocresol green and methyl red). The ammonium formed was then titrated with $\mathrm{HCl}$.

\section{Preparation of enzymatic extracts}

Aliquots of each sample $(30 \mathrm{~g})$ were mixed with $50 \mathrm{~mL} 50$ $\mathrm{mM}$ sodium acetate buffer, $\mathrm{pH} 4.6$, and shaken for $1 \mathrm{~h}$ at 120 $\mathrm{rpm}$. The extract was filtered through a $0.45-\mu \mathrm{m}$ Millipore membrane.

\section{Decolorization of Remazol Brilliant Blue R (RBBR)}

Aliquots of the extract $(2.5 \mathrm{~mL})$ were transferred to test tubes containing $25 \mu \mathrm{L}$ of an RBBR solution $\left(1 \mathrm{mg} \mathrm{L}^{-1}\right)$ and incubated for $2 \mathrm{~h}$ at $28 \pm 0.2^{\circ} \mathrm{C}$. After, the reaction was stopped by heating to $100^{\circ} \mathrm{C}$, followed by immersion in water for $10 \mathrm{~min}$. A $200 \mu \mathrm{L}$ aliquot of the enzymatic extract was mixed with $1.8 \mathrm{~mL}$ distilled water and placed in a quartz cuvette $(1 \mathrm{~cm}$ optical path length) and absorbance was read at $585 \mathrm{~nm}$. RBBR decolorization was compared to a control consisting of enzymatic extract pre-heated to $100^{\circ} \mathrm{C}$ in a water bath for enzyme denaturation.

\section{Laccase}

The reaction mixture contained $500 \mu \mathrm{L}$ of the extract, $500 \mu \mathrm{L}$ $50 \mathrm{mM}$ sodium acetate buffer and $1 \mathrm{~mL}$ of a $5 \mathrm{mM} 2,2$-azino-bis (3-ethylbenzothiazoline-6-sulfonic acid) diammonium salt (ABTS) solution in a volume of $2 \mathrm{~mL}$. The increase in absorbance was determined over a period of $10 \mathrm{~min}$. One enzymatic unit was defined as the amount of enzyme able to oxidize $1 \mu \mathrm{M}$ ABTS $\min ^{-1} \mathrm{~L}^{-1}$ of the culture filtrate ( 3 , modified).

\section{Loss of organic matter}

Ten grams (dry base) of a mixture of sugarcane bagasse, soy flour and soluble starch ( $\mathrm{C} / \mathrm{N}$ ratios as described above) were weighed into $250 \mathrm{~mL}$ glass flasks and humidity was adjusted to $70 \%$. The total content of each sample was dried in an oven 
for $24 \mathrm{~h}$ at $100^{\circ} \mathrm{C}$. The percentage of total organic matter was calculated by the difference in weight.

\section{RESULTS AND DISCUSSION}

The loss of organic matter in the L. crinitus and P. castanella inocula was close to $10 \%$ at the end of the 30 days of incubation. Considering that the degradation rate follows a first-order equation, the organic matter degradation rates can be represented by the following exponential equations: $L$. crinitus: $\mathrm{y}=100.39 \mathrm{e}^{-0.0034 \mathrm{x}}\left(\mathrm{r}^{2}=0.9662\right)$ and $P$. castanella: $\mathrm{y}=100.31$ $\mathrm{e}^{-0.0038 \mathrm{x}}\left(\mathrm{r}^{2}=0.9674\right)$. This loss of organic matter of less than $10 \%$ up to 30 days of incubation has also been reported by Maziero (19) for Pleurotus species cultured on wheat straw. Generally, fungal inocula are used after 21 days of incubation since, according to Matheus (14), complete colonization of the substrate is observed for both fungi after this period.

No significant variations in $\mathrm{pH}$ were observed for the $L$. crinitus or $P$. castanella inocula at the end of the 30 days, with the $\mathrm{pH}$ remaining at about 4. Capelari (5) observed that Pleurotus and Agrocybe perfecta strains grown on solid substrate (wheat straw) also tend to always maintain an acid $\mathrm{pH}$.

The dry biomass of L crinitus was estimated to be $20.11 \mathrm{mg}$, at the fifth day, increasing to $111.97 \mathrm{mg}$ when the fungus was 30 day old. $P$. castanella produced $48.30 \mathrm{mg}$ dry biomass at 5 days of incubation and increased to $128.58 \mathrm{mg}$ at 30 days. Both fungi showed a constant growth until 30 days and did not enter in the stationary phase. In 20 days of growth, a decrease in the ergosterol recovering was observed. The same was observed by Silva (24) in L. crinitus and P. castanella cultures. Silva (24) associated the decay with variations in the ergosterol rate during fungal grown and admitted the possibility of an underestimation of the biomass amount by this biochemical marker. Despite the fact that the synthesis and distribution of sterols in the fungal cells vary during the micelial growth, the ergosterol seems to be a good biomass indicator for both species in solid-state fermentation.

The comparison of the colonization rates obtained for $L$. crinitus by visual analysis and quantification of biomass by ergosterol showed that visual analysis overestimated colonization since the fungus colonizes the substrate more rapidly on the surface than inside the substrate mass. Visual assessment of $P$. castanella seemed to underestimate substrate colonization during the first days of growth, with colonization being overestimated only after 20 days of incubation. This finding is probably due to the fact that the mycelium of this fungus is very thin and hyaline, in contrast to the mycelium of L. crinitus (Fig. 1).

The initial $\mathrm{C} / \mathrm{N}$ ratios of the substrates used for inoculation of L. crinitus and P. castanella were 80 and 58, respectively, and decreased to 60 and 43 after 30 days of incubation, respectively (Fig. 2). Matheus and Bononi (15) tested various $\mathrm{C} / \mathrm{N}$ ratios in order to favor the mineralization of hexachlorobenzene in soil and demonstrated that variations in the $\mathrm{C} / \mathrm{N}$ ratio influence the

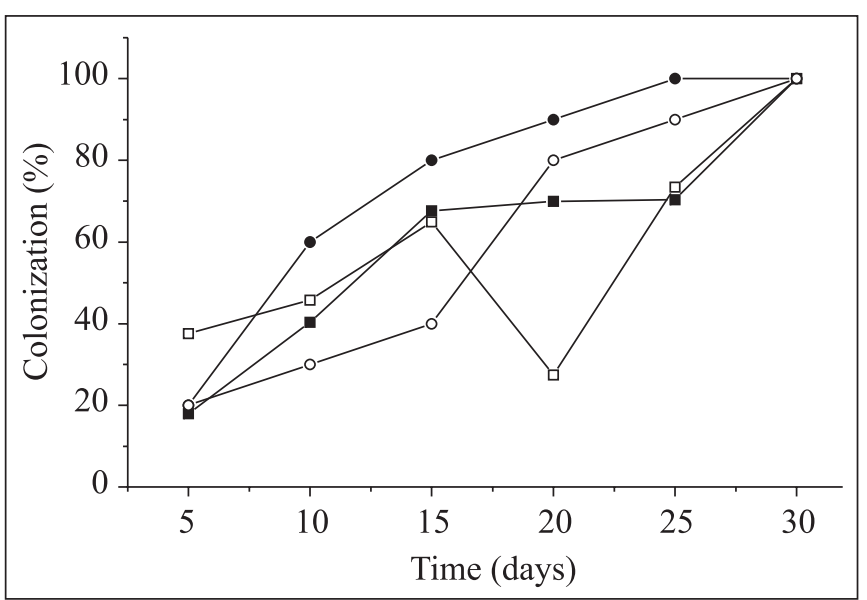

Figure 1. Substrate colonization evaluated by quantification of the biomass of L. crinitus ( $\square$ ) and P. castanella $(\square)$, and by visual analysis of the growth of L. crinitus $(\bigcirc)$ and $P$. castanella (O).

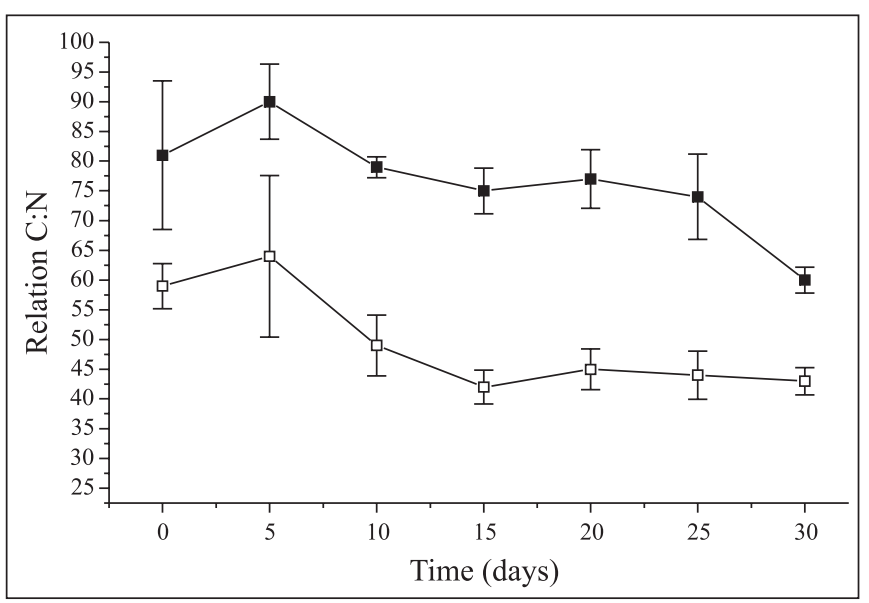

Figure 2. $\mathrm{C} / \mathrm{N}$ ratio of the substrate inoculated with $L$. crinitus ( $\square$ ) and P. castanella ( $\square$ ) during the incubation period.

P. castanella inoculum on degradation, with maximum mineralization of hexachlorobenzene being observed at a $\mathrm{C} / \mathrm{N}$ ratio of 90 . The same effect on hexachlorobenzene degradation was not observed for L. crinitus. Thus, special care should be taken in the preparation of the $P$. castanella inoculum since the chemical and nutritional characteristics of sugarcane bagasse might be altered depending on storage time and conditions (1).

L. crinitus produced the highest laccase activity at 10 days of incubation $\left(0.351 \mathrm{U} \mathrm{g}^{-1}\right)$ and $27 \%$ decolorization of RBBR, whereas $P$. castanella produced the highest laccase activity at 5 days $\left(1.340 \mathrm{U} \mathrm{g}^{-1}\right)$ and $29 \%$ decolorization. After the fifth day, the decolourization rate produced by $P$. castanella had a decrease (Fig. 3). Most basidiomycetes present a higher activity 
Fungal inoculum in soil remediation

of ligninolytic enzymes during the first 15 days of incubation $(5,6,11,12,20,22,23)$. Ullah et al. $(25)$, in a study on the degradation of phenolic compound residues by Coriolus versicolor, observed that the inoculum used after 21 days of incubation promoted removal of $100 \%$ of chlorophenols, suggesting that the physiological age of the basidiomycete inoculum that provides the best conditions for bioremediation is about 10 and 15 days old.

$P$. castanella and $L$. crinitus produced enzymatic activity peaks before they were 21 days old ( 5 and 10 days, respectively). Although larger colonization was observed at the 21 st day, enzymatic production data suggest that younger inocula can be used.

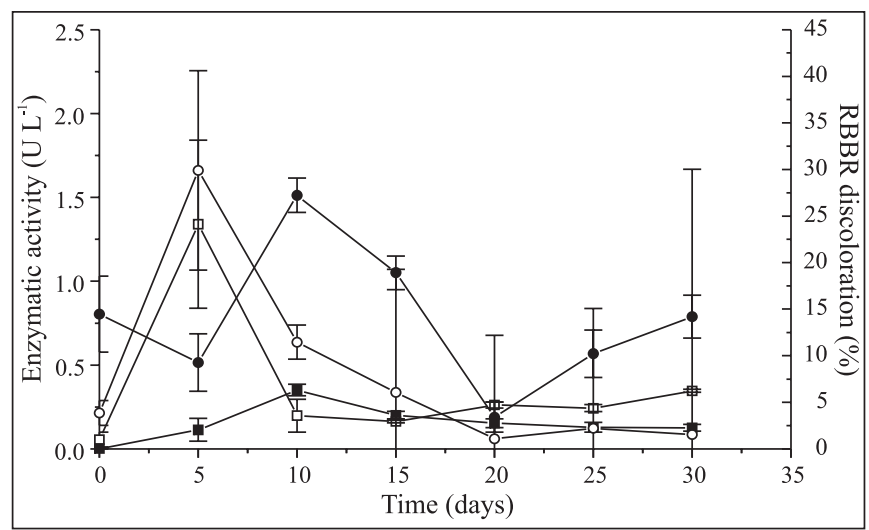

Figure 3. Decolorization of the RBBR dye during the incubation period of $L$. crinitus $(O)$ and $P$. castanella $(O)$. Laccase units produced per liter of extract of $L$. crinitus $(\square)$ and $P$. castanella ( $\square$ ) during culture on solid substrate.

\section{CONCLUSIONS}

In conclusion, $\mathrm{pH}$ stability of the inocula in the acid rage permits enzymatic activity throughout the culture period. Special attention should be paid to the analysis of colonization by each species. The ergosterol quantification has been a good method for the biomass estimation and colonization, since different rates were observed for different growth stages. The best age of $P$. castanella and L. crinitus inocula in bioremediation tests is about 10 and 15 days of incubation, respectively when the nutrients are available to guarantee fungal survival, vigorous colonization, biomass increasing and active enzymatic system.

\section{ACKNOWLEDGMENT}

We thank FUNDEPAG for the financial support and the research team from the Laboratório de Micologia e Liquenologia, Instituto de Botânica, where this study was conducted.

\section{RESUMO}

\section{Caracterização de inóculo fúngico em biorremediação de solo}

Estudos indicam capacidade de basidiomicetos em degradar organopoluentes recalcitrantes. Porém, ainda não foi padronizada a idade do inóculo fúngico a ser aplicado para que ocorra uma degradação mais efetiva. O critério utilizado é colonização total do substrato. Psilocybe castanella CCB444 e Lentinus crinitus CCB274 têm sido avaliados em solos com hexaclorobenzeno. No presente trabalho, foram caracterizadas as condições fisiológicas dos inóculos fúngicos em substrato sólido (bagaço de cana-de-açúcar, amido e farinha de soja). Determinou-se a colonização do substrato, perda de matéria orgânica, variação de pH, carbono orgânico, nitrogênio total, biomassa fúngica e atividade enzimática durante 30 dias de incubação. A colonização do substrato foi quase completa após 20 dias, para ambos os fungos, restando cerca de $90 \%$ de matéria orgânica nos substratos. $\mathrm{O}$ pH permaneceu ácido durante incubação. A maior produção enzimática foi aos 10 dias para $L$. crinitus e aos 5 dias para $P$. castanella. Os fungos apresentaram crescimento até os 30 dias. A relação $\mathrm{C} / \mathrm{N}$ dos inóculos variou pouco. Conclui-se que, inóculos entre 10 e 15 dias de idade podem ser utilizados, pois ainda restam nutrientes suficientes para manter a sobrevivência do fungo, colonização vigorosa do substrato, biomassa crescente e sistema enzimático ativo, permitindo seu crescimento no solo.

Palavras chave: enzimas ligninolíticas, basidiomicetos, inóculo fúngico, ergosterol

\section{REFERENCES}

1. Aluam, A.; Khan, S.M. (1989). Utilization of sugar industry for the production of filamentous protein in Pakistan. Mush. Sci., 12(2), 15-22, apud Maziero, R. (1990). Substratos alternativos para cultivo de Pleurotus spp. São Paulo, Brasil, 135p. (M.Sc. Dissertation. Instituto de Biociências, USP).

2. Bononi, V.L.R. (1997). Biodegradação de organoclorados no solo por basidiomicetos lignocelulolíticos. In: Melo, I.S.; Azevedo, J.L. (eds) Microbiologia ambiental. Embrapa - CNPMA. São Paulo, Brasil, p.243-267.

3. Bourbonnais, R.; Paice, M.G. (1988). Veratryl alcohol oxidases from the lignin-degrading basidiomycete Pleurotus sajor-caju. Biochem. J., 255, 445-450.

4. Brasil, Comissão Nacional de Segurança Química - CONASQ. (2003) Perfil Nacional da gestão de substâncias químicas. Ministério do Meio Ambiente. Brasília, 382p

5. Capelari, M. (1996). Atividade biodegradadora e cultivo de três espécies comestiveis de basidiomicetos: Pleurotus spp. e Agrocybe perfecta (Rick) Sing. São Paulo, Brasil, 154p. (Doctoral Thesis. Instituto de Biociências, USP).

6. D'Souza, T.M.; Merritt, C.S.; Reddy, C.A. (1999). Lignin-modifying enzymes of the white rot basidiomycete Ganoderma lucidum. Appl. Environ. Microbiol., 5307-5313. 
7. Häggblom, M.M. (1992). Microbial breakdown of halogenated aromatic pesticides and related compounds. FEMS Microbiol. Rev., 103, 29-72.

8. Kiehl, E.J. (1985). Fertilizantes orgânicos. Ed. Agronômica CERES Ltda. São Paulo, Brasil.

9. Kirk, T.K.; Farrell, R.L. (1987). Enzymatic "combustion": The microbial degradation of lignin. Annual Rev. Microbiol., 41, 465-505.

10. Lamar, R.T.; White, R.B. (2001). Microremediation - commercial status and recent developments. The sixth international in situ and on-site, California, USA, p.263-278.

11. Machado, C.F. (2003). Influência do nitrogênio e do óleo de soja na atividade ligninolítica de Trametes villosa CCB176 e Psilocybe castanella CCB444. São Paulo, Brasil, 100p. (M. Sc. Dissertation. Instituto de Biociências, UNESP).

12. Machado, K.M.G.; Fabris, C.; Bononi, V.L.R. (1998). Screening of basidiomycetes for xenobiotic degradation. Labs, 3, 53.

13. Machado, K.M.G.; Matheus, D.R.; Monteiro, R.T.R.; Bononi, V.L.R. (2005). Biodegradation of pentachlorophenol by tropical basidiomycetes in soils contaminated with industrial residues. World J. Microbiol. Biotechnol., 21, 297-301.

14. Matheus, D.R. (2003). Otimização da biodegradação de HCB por fungos basidiomicetos em solos contaminados com resíduos industriais. São Paulo, Brasil, 161p. (Doctoral thesis - Instituto de Biociências, UNESP).

15. Matheus, D.R.; Bononi, V.L.R. (2002). C/N Ratio and vegetable oil to mineralize ${ }^{14} \mathrm{C}$-hexachlorobenzene by white-rot-fungi. In: Gavaskar, A.R.; Chen, A.S.C. (eds). Remediation of chlorinated and recalcitrant compounds. Monterey, CA.

16. Matheus, D.R.; Bononi, V.L.R.; Machado, K.M.G. (2000). Biodegradation of hexachlorobenzene by basidiomycetes in soil contaminated with industrial residues. World J. Microbiol. Biotechnol., $16,415-421$.

17. Matheus, D.R.; Bononi, V.L.R.; Machado, K.M.G. (2001). New basidiomycetes on bioremediation of organochlorine contaminated soil. The sixth international in situ and on-site, California, USA, p.99-106.

18. Matheus, D.R.; Okino, L.K. (1998). Utilização de basidiomicetos em processos biotecnológicos. In: Bononi, V.L.R.; Grandi, R.A.P. (eds) Zigomicetos, basidiomicetos e deutoremicetos - noções básicas de taxonomia e aplicações biotecnológicas. Instituto de Botânica/ SMA, São Paulo, Brasil, p.107-139.

19. Maziero, R. (1990). Substratos alternativos para cultivo de Pleurotus spp. São Paulo, Brasil, 135p. (M. Sc. Dissertation. Instituto de Biociências, USP).

20. Pazarlýoglu, N.K.; Sariisikb, M.; Telefoncu, A. (2005). Laccase: production by Trametes versicolor and application to denim washing. Proc. Biochem., 40, 1673-1678.

21. Pointing, S.B. (2001). Feasibility of bioremediation by white-rot fungi. Appl. Microbiol. Biotechnol., 57, 20-33.

22. Schmidt, K.R.; Chand, S; Gostomski, P.A.; Boyd-Wilson, K.S.H.; Ford, C.; Walter, M. (2005). Fungal inoculum properties and its effect on growth and enzyme activity of trametes versicolor in soil. Biotechnol. Prog., 21, 377-385.

23. Silva, E.M. (2003). Análise do crescimento micelial e das atividades lignocelulolíticas produzidas durante o cultivo de Lentinula edodes em resíduo de Eucalyptus saligna. São Paulo, Brasil, 81p. (M. Sc. Dissertation. Biotecnologia, FAENQUIL).

24. Silva, R.R. Ergosterol para a determinação de biomassa de fungos Lentinus crinitus Berk e Psilocybe castanella Peck em biorremediação de solos. São Paulo, Brasil, 108p. (M.Sc. Dissertation. Instituto de Biociências, UNESP).

25. Ullah, M.A.; Kadhim, H.; Rastall, R.A.; Evans, C.S. (2000). Evaluation of solid substrates for enzyme production by Coriolus versicolor, for use in bioremediation of chlorophenols in aqueous effluents. Appl. Microbiol. Biotechnol., 54, 832-837.

26. Vitali, V.M.V.; Machado, K.M.G.; Andréa, M.M.; Bononi, V.L.R. (2006). Screening mitosporic fungi for organochlorides degradation. Braz. J. Microbiol., 37, 256-261. 